\title{
Respon Pertumbuhan dan Hasil Tanaman Terung (Solanum melongena L.) terhadap Berbagai Dosis Abu Sekam Padi pada Tanah Rawa Lebak
}

\section{(Growth and Yield Response Eggplant (Solanum melongena L.) to Varios Dosage Rice Husk Ash at Lebak Wetland Soil)}

\author{
Fenny Erawati \\ Program Studi Agroteknologi, Sekolah Tinggi Ilmu Pertanian Amuntai \\ Fenny.erawati26@yahoo.co.id
}

\begin{abstract}
ABSTRAK
Terung adalah salah satu sayuran yang digemari oleh masyarakat. Tanah rawa lebak berpotensi untuk budidaya sayuran terung, tetapi yang menjadi permasalahan pada tanah tersebut adalah sifat fisik, kimia, dan biologi tanah yang kurang menguntungkan. Sekam berfungsi untuk menggemburkan tanah sehingga bisa mempermudah akar tanaman menyerap unsur hara. Penelitian ini bertujuan (i) untuk mengetahui respon pertumbuhan dan hasil tanaman terung terhadap berbagai dosis abu sekam padi pada tanah rawa lebak, (ii) mendapatkan dosis abu sekam padi terbaik bagi pertumbuhan dan hasil tanaman terung pada tanah rawa lebak. Penelitian ini dilaksanakan di Desa Hambuku Tengah, Kecamatan Sungai Pandan, Kabupaten Hulu Sungai Utara dari Februari - Mei 2010, penelitian ini mengunakan Rancangan Acak Kelompok (RAK) faktor tunggal dengan 5 perlakuan dan 4 ulangan sehingga diperoleh 20 satuan percobaan, setiap satuan percobaan terdapat 4 tanaman. Faktor yang diuji adalah dosis abu sekam padi perpolibag adalah $a_{0}=0$ atau kontrol, $a_{1}=100 \mathrm{~g}, a_{2}=200 \mathrm{~g}, a_{3}=300 \mathrm{~g}$, dan $a_{4}=400 \mathrm{~g}$. Hasil penelitian menunjukkan bahwa pemberian sekam padi tidak berpengaruh terhadap semua peubah yang diamati dan tidak didapatkan dosis terbaik perlakuan pemberian dosis abu sekam padi.
\end{abstract}

Kata kunci: Terung, tanah, rawa lebak, abu, sekam padi.

\section{ABSTRACT}

Eggplant is one of the vegetables favored by the community. Lebak wetland has the potential for eggplant vegetable cultivation, but the problem with the soil is the physical, chemical and biological properties of the soil that are less favorable. Husk serves to loosen the soil so that it can facilitate plant roots to absorb nutrients. This study aims (i) to determine the growth response and yield of eggplant to various doses of rice husk ash in lebak wetland, (ii) to obtain the best dosage of rice husk ash for growth and yield of eggplant on lebak land. This research was conducted in Hambuku Tengah Village, Sungai Pandan Subdistrict, Hulu Sungai Utara Regency from February - May 2010, this study used a single randomized block design (RBD) with 5 treatments and 4 replications so that 20 experimental units were obtained, each trial unit contained 4 plant. The factor tested was the dose of perpolibag rice husk ash is a $=0$ or control, $a_{1}=100 \mathrm{~g}, a_{2}=200 \mathrm{~g}, a_{3}=300 \mathrm{~g}$, and $a_{4}=400 \mathrm{~g}$. The results showed that giving of rice husk did not affect all variables observed and did not obtain the best dose of dosing treatment for rice husk ash.

Keywords: Eggplant, soil, lebak wetland, ash, rice husk.

\section{PENDAHULUAN}

Komoditas terung sangat potensial untuk dikembangkan secara intensif dalam skala agribisnis sekaligus penyumbang cukup besar terhadap keanekaragaman bahan pangan bergizi bagi penduduk, serta meningkatkan pendapatan bagi para petani khususnya dan penghasil devisa bagi negara (Soetesad dan Muryanti, 1999).
Menurut data dari UPT Pertanian TPH Kecamatan Babirik (2005-2009) produksi tanaman terung pada tahun 2009 mencapai 192 ton.ha $^{-1}$. Lahan rawa lebak selain berpotensi untuk budidaya tanaman pangan seperti padi pada umumnya juga dapat dimanfaatkan sebagai lahan budidaya sayuran. Pracaya (2005) menyatakan bahwa hal yang menjadi permasalahan pada lahan tersebut adalah sifat kimia, biologi, dan fisik tanah yangk urang menguntungkan untuk 
tanaman sayur, antara lain sebagai berikut : (1) pengaruh langsung kemasaman terutama peningkatan kelarutan $\mathrm{Al}, \mathrm{Fe}, \mathrm{Mn}$, dan $\mathrm{H}$, (2) penurunan ketersediaan $\mathrm{P}$ karena adanya interaksi $\mathrm{Fe}$ dan $\mathrm{Al}$, (3) mudahnya terjadi kahat unsur hara, (4) pada tanah asam unsur $\mathrm{Fe}, \mathrm{Cu}, \mathrm{Mn}, \mathrm{Al}$ banyak tersedia namun unsurunsur tersebut akan meracuni tanaman bila tersedia banyak, (5) pada $\mathrm{pH}$ tanah rendah dan tinggi, unsur fosfor banyak terikat pada komponen tanah sehingga sulit untuk diserap akar, (6) memiliki tekstur yang liat atau tidak begitu gembur dan pori - pori tanah sangat kecil sehingga aerasi dan drainasenya kurang, (7) kurangnya mikroorganisme tanah karena tekstur tanah yang padat sehingga sulit untuk hidup.

Abu sekam merupakan hasil pembakaran sempurna yang kaya mineral, baik untuk memperbaiki sifat kimia tanah, mendorong perkembangan sifat organis tanah dan menyumbang hara. Fungsi kimianya adalah melepaskan ikatan asam sehingga unsur hara tersedia bagi tanaman (Lili, 2003).

Sekam dan abu sekam memiliki fungsi mengikat logam berat. Selain itu sekam berfungsi untuk menggemburkan tanah sehingga bisa mempermudah akar tanaman menyerap unsur hara di dalamnya, sekam bakar dianggap memiliki daya serap terhadap air sedikit, tetapi aerasi udaranya sangat baik. Sekam bakar memiliki keuntungan adalah steril, poros, banyak unsur hara ringan untuk mobilisasi. Abu sekam padi sangat kaya akan $\mathrm{Si}$ yang dalam oksidasinya untuk memperbaiki tanah, menaikkan $\mathrm{pH}$ pada laha rawa (Febrynugroho, 2008).

Penelitian ini bertujuan (i) mengetahui respon pertumbuhan dan hasil tanaman terung terhadap berbagai dosis abu sekam padi pada tanah rawa lebak, (ii) mendapatkan dosis abu sekam padi yang terbaik bagi pertumbuhan dan hasil tanaman terung pada tanah rawa lebak.

\section{METODE PENELITIAN}

\section{Tempat dan Waktu Penelitian}

Penelitian dilaksanakan dari bulan Februari - Mei 2010 bertempat di Desa
Hambuku Tengah Kecamatan Sungai Pandan Kabupaten Hulu Sungai Utara.

\section{Bahan dan Alat}

Bahan yang digunakan dalam penelitian ini adalah tanah rawa lebak, benih terung Varietas "Mustang $F_{1}$ ", abu sekam padi, pupuk kandang kotoran itik, polibag, gelas air mineral bekas dan air. Alat yang digunakan adalah cangkul, parang, timbangan, meteran, ember, batang bambu, penggaris, tali, alat tulis, dan kamera.

\section{Rancangan Percobaan}

Penelitian ini merupakan percobaan dilapangan dengan perlakuan faktor tunggal menggunakan Rancangan Acak Kelompok (RAK) dengan pengelompokan berdasarkan tinggi bibit tanaman. Perlakuan dalam penelitian ini terdiri dari 5 taraf dosis abu sekam padi yaitu :

$\mathrm{a}_{0}: 0 \quad$ t. ha $^{-1}$ setara dengan 0 g.polibag ${ }^{-1}$

$\mathrm{a}_{1}: 25 \mathrm{t}^{\text {h ha }}{ }^{-1}$ setara dengan 100 g.polibag ${ }^{-1}$

a $: 50$ t. ha $^{-1}$ setara dengan 200 g.polibag ${ }^{-1}$

a $3: 75 \mathrm{t}^{\text {. ha }}{ }^{-1}$ setara dengan 300 g.polibag ${ }^{-1}$

a4 : 100 t. $^{\text {ha }}{ }^{-1}$ setara dengan 400 g.polibag ${ }^{-1}$

Setiap perlakuan tedapat 4 ulangan sehingga didapat 20 satuan percobaan dan setiap percobaan terdiri 4 tanaman.

Pengamatan yang dilakukan antara lain tinggi tanaman dan jumlah daun umur 7 , 14, 21, 28 dan 35 hari setelah tanam (HST), jumlah cabang, umur tanaman saat berbunga, jumlah bunga pertanaman, jumlah buah pertanaman, panjang buah, dan bobot buah pertanaman.

Data yang diperoleh dilakukan uji kehomogenan ragam Bartlet. Untuk mengetahui pengaruh perlakuan terhadap peubah yang diamati dilakukan analisis ragam menggunakan uji $\mathrm{F}$ pada taraf nyata $5 \%$ atau sangat nyata $1 \%$. Jika $\mathrm{F}$ hitung $>\mathrm{F}$ tabel $5 \%$ dan $1 \%$ berarti perlakuan dosis abu sekam padi memberikan respon nyata atau sangat nyata pada setiap peubah yang diamati, kemudian dilanjutkan dengan uji beda nilai tengah menggunakan uji jarak ganda Duncan (DMRT) pada taraf uji $5 \%$. 


\section{HASIL DAN PEMBAHASAN}

Hasil pengukuran tinggi tanaman dan jumlah daun pada umur 7, 14, 21, 28 dan 35 HST, jumlah cabang, umur tanaman berbunga, jumlah bunga pertanaman, jumlah buah pertanaman, panjang buah, dan berat buah dengan hasil analisis ragam menunjukan tidak terdapat respon pada semua peubah yang diamati terhadap perlakuan yang diberikan.

Berdasarkan hasil penelitian pemberian dosis abu sekam padi menunjukkan pengaruh terhadap kesuburan tanah yaitu sifat fisik tanah rawa lebak yang awalnya memiliki tekstur liat, tidak gembur serta pori-pori yang kecil menjadi tanah yang gembur dengan pori-pori tanah yang cukup sehingga mempermudah pertukaran udara dan penyerapan unsur hara oleh akar. Dapat mempermudah mikro dan makro organisme hidup. Terjadi peningkatan $\mathrm{pH}$ tanah yang semula sebesar 5,59 menjadi 7,24 setelah adanya pemberian abu sekam padi.

Rendahnya pertumbuhan tanaman disebabkan ketersediaan unsur hara di dalam tanah dan perbedaan $\mathrm{pH}$ tanah. Hasil analisis tanah menunjukkan peningkatan $\mathrm{pH}$ dengan pemberian abu sekam padi dan diikuti peningkatan ketersediaan unsur-unsur hara terutama $\mathrm{P}$ dan $\mathrm{K}$ serta penurunan unsur $\mathrm{N}$. Apabila kadar P berlebihan, maka serapan Fe dan $\mathrm{Zn}$ akan terganggu, begitu pula bila di dalam tanah banyak terdapat ion bikarbonat seperti efek pengapuran maka serapan $\mathrm{Fe}$ akan terganggu (Wijaya, 2008). Pada $\mathrm{pH}$ tanah rendah dan tinggi, unsur fosfor banyak terikat pada komponen tanah sehingga sulit untuk diserap akar (Pracaya, 2005).

Peningkatan nilai $\mathrm{pH}$ ini terjadi akibat adanya pertukaran anion antara ion $\mathrm{OH}^{-}$yang terikat pada $\mathrm{Al}$ dan $\mathrm{Fe}$ dengan ion silikat sehingga ion $\mathrm{OH}^{-}$yang terlepas dapat meningkatkan nilai $\mathrm{pH}$ larutan tanah. Yukamgo (2005) menjelaskan mekanisme reaksi dalam tanah sebagai berikut :

$\mathrm{Si}(\mathrm{OH})_{4}+\mathrm{Fe}(\mathrm{OH})_{3}$

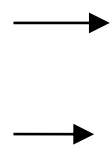

$\mathrm{Fe}(\mathrm{OH})_{2} \mathrm{OSi}(\mathrm{OH})_{3}+\mathrm{OH}^{-}$

$\mathrm{Si}(\mathrm{OH})_{4}+\mathrm{Al}(\mathrm{OH})_{3}$
$\mathrm{Al}(\mathrm{OH})_{2} \mathrm{Osi}(\mathrm{OH})_{3}+\mathrm{OH}^{-}$

Peningkatan nilai $\mathrm{pH}$ tanah juga karena adanya pengaruh logam-logam alkali seperti
$\mathrm{Ca}, \mathrm{Na}, \mathrm{Mg}$ dan K. Pada tanah yang $\mathrm{pH}$ rendah atau bersifat masam, beberapa unsur mikro lebih banyak tersedia terutama dalam bentuk kation diantaranya $\mathrm{Fe}, \mathrm{Mn}, \mathrm{Zn}$ dan $\mathrm{Cu}$. Bila $\mathrm{pH}$ tanah naik maka bentuk ion dari kation tersebut berubah menjadi hidroksida/oksida yang tidak tersedia bagi tanaman. Namun pada unsur Mo dan B justru terjadi reaksi sebaliknya, dimana ketersediaannya akan meningkat bila $\mathrm{pH}$ naik. Hal yang perlu diperhatikan dalam hubungannya dengan tanamanan adalah bahwa setiap jenis tanaman berbeda-beda kebutuhannya akan unsur mikro sehingga kelebihan sedikit saja akan bersifat racun bagi tanaman (Wijaya, 2008).

Dari hasil analisis ragam menunjukkan tidak terdapat respon pada semua peubah yang diamati terhadap pemberian dosis abu sekam padi. Hal ini dikarenakan dosis abu sekam padi yang digunakan pada penelitian ini berlebih yaitu $50 \mathrm{t}$. ha ${ }^{-1}$ atau setara dengan 200 g.polibag ${ }^{-1}$ padahal pemberian abu sekam yang dianjurkan adalah $12 \mathrm{t}$. ha ${ }^{-1}$ atau 48 g.polibag ${ }^{-1}$ (Masullili, 2004), sedangkan menurut Prihmantoro (1996), pemberian bahan organik yang sesuai untuk tanaman terung adalah sebanyak $10-15$ t. ha $^{1}$ sehingga dengan pemberian bahan organik yang berlebih dalam hal ini adalah abu sekam padi dapat meningkatkan unsur hara mikro yang terdapat pada abu sekam padi yaitu $\mathrm{Si}$ dan meningkatkan unsur hara makro ( $\mathrm{P}$ dan $\mathrm{K})$ serta menyumbang $\mathrm{Ca}, \mathrm{Mg}$ dan mineral lain yang memiliki sifat antagonistik, sinergistik atau kompetitif diantara unsur hara yang apabila keberadaannya tidak sesuai dengan yang diharapkan oleh tanaman akan berakibat meracuni tanaman sehingga pertumbuhannya terganggu.

Abu sekam padi banyak mengandung $\mathrm{Si}$, sehingga dengan terjadinya peningkatan $\mathrm{Si}$ maka ketersediaan unsur $\mathrm{P}$ dan $\mathrm{K}$. meningkat, namun penurunan terhadap unsur $\mathrm{N}$ yang mana menurut Wijaya (2008) unsur $\mathrm{N}$ ini sangat diperlukan oleh tanaman untuk menyusun klorofil, tanaman yang kekurangan unsur ini membentuk daun-daun yang kecil dan pertumbuhan perakaran tanaman juga terhambat yang mengakibatkan terganggunya pertumbuhan tanaman. Unsur $\mathrm{K}$ berperan dalam mengaktifkan enzim dalam 
metabolisme dan biosintesis, menjaga tekanan turgor sel. Apabila tanaman banyak unsur $\mathrm{K}$ maka akan membentuk fotosintat yang banyak sehingga terhambat dan terhentinya pertumbuhan tanaman, daundaun berukuran kecil yang disertai adanya klorosis daun serta daun menjadi keriting seperti terkena serangan virus karena kurangnya unsur $\mathrm{Zn}$ yang disebabkan banyaknya kadar P (Wijaya, 2008).

Dari hasil penelitian menunjukkan pemberian abu sekam padi tidak memberikan pengaruh karena penurunan unsur $\mathrm{N}$ yang mengakibatkan terganggunya atau terhambatnya inisiasi bunga, kerontokan bunga, dan terganggunya pembentukan biji pada beberapa tanaman saat periode pembungaan dan masalah ini penyebab rendahnya hasil. Peningkatan $P$ menyebabkan tanaman makin banyak menangkap cahaya matahari dan mengubah menjadi energi biokimia yang pada hakikatnya dapat menurunkan jumlah bunga karena suhu jadi meningkat. Terjadinya penurunan hasil pada penelitian karena kurangnya unsur $\mathrm{Ca}$ sebab unsur ini mencegah kematian pucuk, kerontokan bunga dan buah muda akibat terhambatnya pertumbuhan tabung tepung sari pada proses penyerbukan (Wijaya, 2008).

Penurunan hasil dengan pemberian dosis abu sekam yang tinggi menyebabkan ketidakseimbangan unsur hara di dalam tanah, terlalu banyak unsur $\mathrm{P}$ dalam tanah dapat menyebabkan kekurangan $\mathrm{Cu}$, dan $\mathrm{Zn}$. Tanaman membutuhkan $\mathrm{Zn}$ sebagai pembentukan protein dan pematangan biji, sedangkan $\mathrm{Cu}$ sebagai penyusun enzim, pembentukan klorofil dan metabolisme karbohidrat. Tanaman yang kekurangan unsur $\mathrm{Cu}$ akan menurunkan kemampuan fotosintesis, mudah terinfeksi jamur, terjadi penundaan pembungaan serta mengurangi jumlah pucuk yang berbunga akibat lain adalah tidak mengembangnya bunga (Wijaya, 2008), hal inilah yang menyebabkan kurangnya hasil tanaman terung yang mendapat perlakuan abu sekam padi yang berlebih.

\section{KESIMPULAN}

Tidak terdapat respon tinggi tanaman, jumlah daun, jumlah cabang, umur tanaman saat berbunga, jumlah bunga pertanaman, jumlah buah pertanaman, panjang buah, dan bobot buah pertanaman terhadap pemberian berbagai dosis abu sekam padi.

Tidak terdapat dosis terbaik abu sekam padi bagi pertumbuhan dan hasil tanaman terung pada tanah rawa lebak.

\section{DAFTAR PUSTAKA}

Febrynugroho. 2008. Manfaat Abu Sekam dan Sekam Padi. http://www. Pustaka.com. Diakses tanggal 27 Oktober 2009.

Lili. 2003. Manfaat Abu Sekam Padi. http://www.yahoo.co.id/gwt/x. Diakses tanggal 20 Pebruari 2010.

Masullili, A. 2004. Analisis pertumbuhan kedelai pada histosols dengan perlakuan abu sekam padi dan berbagai tingkat lengas tanah. http://upb.ac.id/Jurnal/Vol. Diakses tanggal 10 Agustus 2010.

Pracaya. 2008. Bertanam Sayuran Organik di Kebun, Pot dan Polibag. Penebar Swadaya. Jakarta.

Prihmantoro. 1996. Meтupuk Tanaman Sayur. Media Utama. Bekasi.

Soetasad, A dan Sri Muryani. 1999. Budidaya Terung Lokal dan Terung Jepang. PT. Penebar Swadaya. Jakarta.

UPT Pertanian TPH Kecamatan Babirik. 2009. Data Produksi Tanaman Terung di Kecamatan Babirik.

Wijaya, K. A. 2008. Nutrisi Tanaman Sebagai Penentu Kualitas Hasil dan Resestensi Alami Tanaman. Prestasi Pustaka Publisher. Jakarta. 